\title{
Linking functional traits with tree growth and forest productivity in Quercus ilex forests along a climatic gradient
}

\author{
Pablo Salazar Zarzosa ${ }^{\text {a,* }}$, Aurelio Diaz Herraiz ${ }^{\text {a,c }}$, Manuel Olmo ${ }^{a}$, Paloma Ruiz-Benito ${ }^{\text {dee }}$, Vidal Barrón ${ }^{\text {b }}$, \\ Cristina C. Bastias ${ }^{\text {f,g }}$, Enrique G. de la Riva ${ }^{\mathrm{h}}$, Rafael Villar ${ }^{\mathrm{a}}$ \\ a Área de Ecología, Facultad de Ciencias, Universidad de Córdoba, Campus de Rabanales, 14071 Córdoba, Spain \\ b Departamento de Agronomía, Escuela Técnica Superior de Ingenieros Agrónomos y de Montes, Universidad de Córdoba, Campus de Rabanales, 14071 Córdoba, Spain \\ c Instituto Federal de Ciência e Tecnologia do Amazonas, Campus Humaitá, 69800.000, Brazil \\ d Ecology and Forest Restoration Group, Life Science Department, University of Alcalá, Ctra. Madrid-Barcelona, Km. 33,600, 28805 Alcalá de Henares, Spain \\ e Remote Sensing Research Group, Department of Geology, Geography and Environment, University of Alcalá, Calle Colegios 2, 28801 Alcalá de Henares, Spain \\ ${ }^{\mathrm{f}}$ CEFE, Univ Montpellier, CNRS, EPHE, IRD, Univ Paul Valéry Montpellier 3, Montpellier, France \\ ${ }^{g}$ Departamento de Ingeniería Forestal, Escuela Técnica Superior de Ingeniería Agronómica y de Montes, Universidad de Córdoba, Córdoba, Spain \\ ${ }^{\text {h }}$ Department of Ecology, Brandenburg University of Technology, 03046 Cottbus, Germany
}

\section{H I G H L I G H T S}

- Aridity is the main environmental factor affecting leaf functional traits.

- Soil nutrients are the main drivers of the relative growth rate in Quercus ilex.

- Forest productivity is explained by forest biomass and relative growth rate.

- Trait intraspecific variability has a significant effect on forest biomass.

\section{G R A P H I C A L A B S T R A C T}

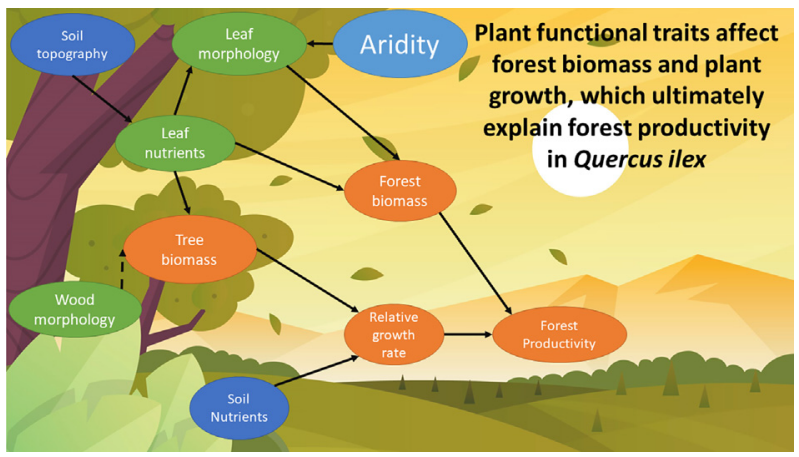

\begin{abstract}
A B S T R A C T
Plant functional traits are highly plastic to changes in climatic factors and nutrient availability. However, the intraspecific plant response to abiotic factors and the overall effect on tree growth and productivity is still under debate. We studied forest productivity for 30 Quercus ilex subsp. ballota forests in Spain along a broad climatic gradient of aridity (mean annual precipitation from 321 to $858 \mathrm{~mm}$ ). We used linear mixed models to quantify the effect of climatic and edaphic (soil nutrients, topography, and texture) factors on tree functional traits (leaf and branch traits), and subsequently, the effect of such functional traits and abiotic factors on the relative growth rate (RGR) of adult trees. We used piecewise structural equation models (SEMs) to determine the causal effect of intrinsic and extrinsic factors on forest productivity. Our results showed that tree functional traits were mainly explained by climatic and edaphic factors. Functional traits and tree biomass explained forest biomass and RGR, respectively, which ultimately explained forest productivity. In conclusion, intraspecific variability of functional traits has a significant effect on plant biomass and growth, which ultimately may explain forest productivity in Quercus ilex forests.
\end{abstract}

(c) 2021 The Authors. Published by Elsevier B.V. This is an open access article under the CC BY license (http://creativecommons.org/licenses/by/4.0/).

\footnotetext{
* Corresponding author.

E-mail address: pcsalazarz@gmail.com (P. Salazar Zarzosa).
} 


\section{Introduction}

Functional traits are biological attributes that directly or indirectly affect plant fitness and generally reflect plant adaptation to local environmental conditions (Lavorel et al., 1997; Violle et al., 2007). Functional trait variability allows plants to minimize their building costs and maximize functional efficiency. Understanding how functional traits vary across environmental gradients is critical to determine plant functioning and their ecological strategies in contrasting environmental conditions (Westoby, 1998), especially relevant under the ongoing climatic change scenario. For instance, drought avoidance creates a trade-off between water conservation and nutrient acquisition. For example, wood density and leaf mass per area (LMA) increase in arid environments to reduce the risk of cavitation and increase defense functions. However, this has the cost of a lower plant biomass and growth (Chave et al., 2009; Vilà-Cabrera et al., 2015).

Empirical studies have shown that functional traits are related to abiotic variables with a direct effect on the relative growth rate (RGR; Chave et al., 2009; Salgado-Luarte and Gianoli, 2017; Violle et al., 2007). At the local scale, the functional traits have an important effect on RGR (Chaturvedi et al., 2011; Dong et al., 2020). Whereas at larger spatial scales, tree size is generally used as the main plant trait and abiotic conditions are summarized through temperature or precipitation to explain plant growth (de la Riva et al., 2016a; Moore et al., 2020). In fact, a weak relationship between LMA and RGR has been found when plant size is taken into account (Gibert et al., 2016; Wright et al., 2010), arguing that LMA is not a clear physiological trait and should be replaced by mechanistic traits (like leaf nutrients or wood density) more associated with plant fitness (Rosas et al., 2019). In any case, the direct and indirect effect of functional traits on RGR is key to understand how plants adapt to environmental changes, and whether or not this has any effect on ecosystem functioning.

Additionally, variation in RGR is associated with intrinsic factors as the tree biomass and abiotic factors such as soil nutrient availability and climate (Antúnez et al., 2001; Cornelissen and Thompson, 1997; Lambers et al., 2008). However, it is still uncertain whether these factors have a direct or indirect effect on plant growth. For instance, Bu et al. (2019) found that changes in abiotic conditions did not directly affect plant growth, but indirectly via changes in plant functional traits. Similarly, it has been shown that RGR negatively correlates with tree biomass during the stand development; however, this relationship disappears when the trees reach the maturity stage (Ruiz-Benito et al., 2015). Therefore, the source of variation in RGR is currently a growing field of research.

Several large-scale studies have analyzed how differences in functional traits between species determine growth responses to plantplant interactions and forest demography (Kunstler et al., 2016; Ruiz-Benito et al., 2017). It is not well known however the role of intraspecific trait variability in determining forest responses (Wang and Hamzah, 2018), although it has been suggested that functional trait intraspecific variability determines species distribution under a warming climate (Valladares et al., 2015). Furthermore, it has been shown that intraspecific variability can be larger than interspecific variability (Fajardo and Siefert, 2016), and this variation influences the interactions among organisms that ultimately drive the functional community (Bastias et al., 2017; Siefert et al., 2015). Therefore, understanding the source of intraspecific functional trait variations, as well as its contribution to plant growth and ecosystem function is critical to understand forest responses under changing conditions. We focus on the intraspecific variability of Quercus ilex (subsp. ballota) dominated forests, a key tree species in Mediterranean forests characterized by high plasticity and resistance to drought (Aranda et al., 2004; Quero et al., 2006).Our goal is to assess whether abiotic factors directly affect forest productivity or indirectly influence on it via changes in functional traits and RGR, and how such direct and indirect effects might be disentangled (Fig. 1). We hypothesized that the forest productivity $\left(\mathrm{kg} \mathrm{ha}^{-1}\right.$ year $^{-1}$ ) is related to the forest biomass
( $\mathrm{kg} \mathrm{ha}^{-1}$ ) and RGR $\left(\mathrm{g} \mathrm{kg}^{-1}\right.$ year $^{-1}$ ). The forest biomass can be decomposed in the mean tree biomass and the tree density, whereas RGR can be explained by functional traits and abiotic factors. To study this, we combined data from the Spanish National Forest Inventory (NFI) with field sampling to include functional trait data and soil characteristics. Our specific objectives are: (1) to determine how abiotic factors (climate and soil properties) affect functional traits; (2) to know the effect of abiotic factors, functional traits, and forest structure (tree biomass and density) on relative growth rate; and (3) to model forest productivity as a result of these ecological, physiological and environmental factors.

\section{Material and methods}

\subsection{Study species}

The Iberian Peninsula is characterized by evergreen sclerophyllous, semideciduous malacophyllous, and grassland species. Most of the forest landscape is composed of cleared oak forest of Quercus ilex or Q. suber, constituting the so-called "dehesas" in Spain and Portugal (Gil-pelegrín and Peguero-Pina, 2017). Fluctuating conditions with wet springs and dry summers dominate the Mediterranean climate, which restricts plant growth and forest production (Flexas et al., 2014). We studied Quercus ilex subsp. ballota (hereafter Q. ilex), an evergreen-sclerophyllous and drought-resistant species, which is extensively distributed throughout the Mediterranean basin (Caudullo et al., 2017; Quero et al., 2011; Fig. 2). This species is shade-tolerant characterized by an anisohydric behavior (Sade et al., 2012) and the leaf lifespan ranges from 2 to 3 years (Gratani et al., 2000). It is deeprooted and has a great capacity to maintain high stomatal conductance during long dry periods (Barbero et al., 1992; Quero et al., 2011).

\subsection{Spanish Forest Inventory and experimental design}

The Spanish Forest Inventory is a nationwide program that establishes $50 \mathrm{~m}$ diameter plots in forested areas of Spain each $\mathrm{km}^{2}$. In the NFI plots, adult trees [i.e. those with DBH (diameter at breast height) greater or equal to $7.5 \mathrm{~cm}$ and height greater or equal to $1.30 \mathrm{~m}$ ] were measured using a variable radius sampling protocol. Thus, trees were measured in a 5,10 , and $15 \mathrm{~m}$ radius subplots if the DBH was lower than $12.5,22.5$ and $42.5 \mathrm{~cm}$, respectively. Trees in the $25 \mathrm{~m}$ radius subplot were only measured if the DBH was higher than $42.5 \mathrm{~cm}$. For each tree measured it is included the $\mathrm{DBH}$, tree height and species identity.

We selected thirty plots dominated by $Q$. ilex from the inventory covering six contrasting climatic regions according to Köppen-Geiger Climate Classification. The plots were selected from the NFI database within certain criteria based on the plot accessibility, location and the Q. ilex percentage abundance in the plot. Five plots were randomly chosen within each climatic region (in a nested design), and the distance between plots of each region (13.5 $\mathrm{km}$ on average) was considered to avoid pseudoreplication. On average, $Q$. ilex represented $90 \%$ of the total forest biomass of the plot, ranging from 60 to $100 \%$ (with a total dominance in 18 plots). The mean annual temperature varies between 10.9 and $17.4{ }^{\circ} \mathrm{C}$ and the annual precipitation varies from 357 to 858 $\mathrm{mm}$. More details about the selected plots can be found in Table 1.

We used the DBH data from the third National Forest Inventory (1997-2007, NFI3) and we calculated tree biomass ( $\mathrm{kg}$ tree $\left.^{-1}\right)$ using the allometric equations from Ruiz-Peinado et al. (2011). For each plot, the forest biomass $\left(\mathrm{Mg} \mathrm{ha}^{-1}\right)$ was calculated as the sum of the individual tree biomass considering the subplot where the tree belongs (i.e. 5, 10, 15 and $25 \mathrm{~m}$ radius subplots) (Ruiz-Benito et al., 2014). Similarly, we calculated tree density of each subplot as the sum of tree density (number of trees ha ${ }^{-1}$ ) of each radius subplots. In 2018, we re-measured the DBH of all trees in each selected plot to calculate tree biomass increment and forest biomass increment in the last eleven years (2007-2018 period). Moreover, we collected leaf and branch 


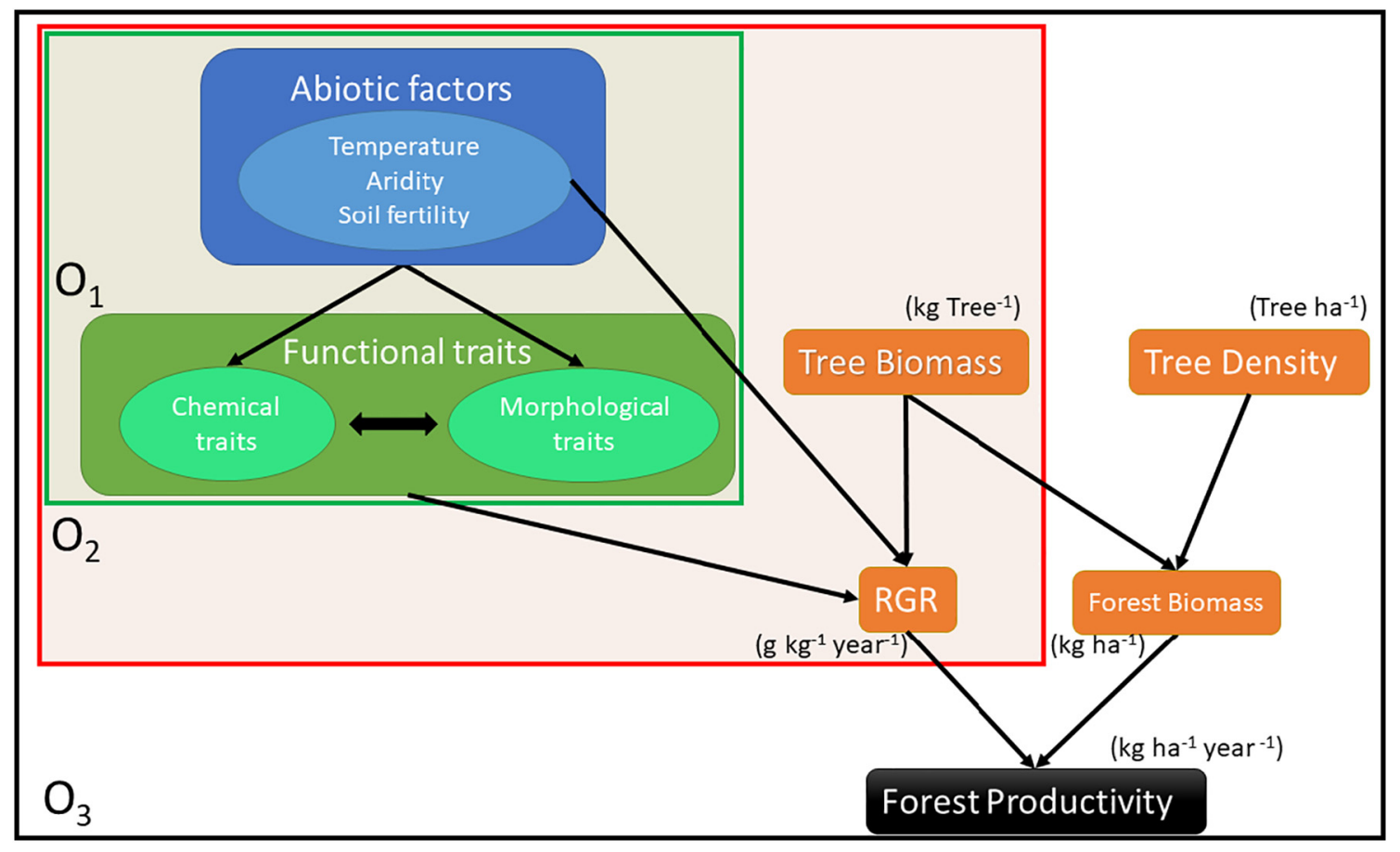

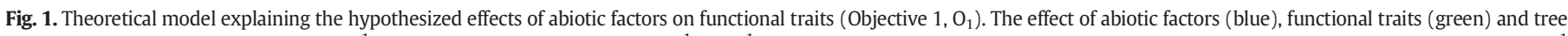

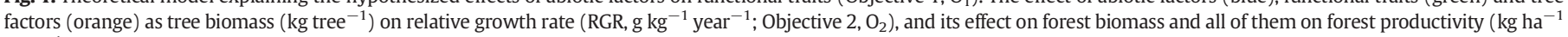
year $^{-1}$, black) (Objective $3, \mathrm{O}_{3}$ ).

material from 5 random trees to measure key functional traits related to plant ecological strategy.

Tree relative growth rate $(\mathrm{RGR})$ was calculated as: $R G R=\left[\operatorname{Ln}\left(B_{2}\right)-\right.$ $\left.\operatorname{Ln}\left(B_{1}\right)\right] /\left[t_{2}-t_{1}\right]$, where $B$ is tree biomass and $t$ is time, with 2 and 1 referring to our sampling survey data (i.e. 2018) and NFI3 data (i.e. 2007), respectively. RGR is a standardized measure of growth with the benefit of avoiding, as far as possible, the inherent differences in scale among trees of different size, thus their performances can be compared on an equitable basis (Pommerening and Muszta, 2015; Villar et al., 2017). Forest productivity ( $\mathrm{kg} \mathrm{ha}^{-1}$ year $^{-1}$ ) was calculated as the difference of forest biomass between our sampling data and NFI3 for trees alive in both consecutive inventories divided by the time difference between surveys (between 9 and 11 years) with a daily resolution.

\subsection{Functional traits measurements}

Leaf and branch material collection was done in late spring and summer, between May and September 2018, when the leaf formation is completed. In each plot, five $Q$. ilex trees were sampled taking two branches per individual. The samples were conservated in a damp paper in a portable refrigerator and transported to the laboratory. Fully mature one-year-old leaves were taken from each branch and processed independently. A subsample of leaves were scanned (excluding petiole) and the leaf area (LA) was measured using Image Pro software (Media Cybernetics, MD, USA). Then, in five leaves we measured the leaf thickness (LT) using a micrometer (Electronic Digital Micrometer Comecta, Barcelona, Spain). After that, the leaves were dried on a stove ( $60{ }^{\circ} \mathrm{C}$ for two days) to calculate leaf dry mass. Leaf mass area (LMA, $\mathrm{g} \mathrm{m}^{-2}$ ) was calculated as dry mass $(\mathrm{g}) /$ leaf area $\left(\mathrm{m}^{2}\right)$, leaf density (LD; $\mathrm{g} \mathrm{cm}^{-3}$ ) as LMA $\left(\mathrm{g} \mathrm{m}^{-2}\right) /$ thickness $(\mu \mathrm{m})$ and leaf dry matter content (LDMC; $\mathrm{g} \mathrm{g}^{-1}$ ) = dry mass $(\mathrm{g}) /$ fresh mass $(\mathrm{g})$. Another leaf subsample was dried on a stove $\left(60^{\circ} \mathrm{C}\right.$ for 2 days) and reserved for nutrient analysis.

To analyze leaf nutrients, leaves were dried at $70{ }^{\circ} \mathrm{C}$ for $24 \mathrm{~h}$ before grinding with a stainless-steel grinder. The leaf $\mathrm{N}$ concentration was measured using an elemental analyzer (Eurovector EA3000), and we also measured the leaf concentrations of macronutrients $(\mathrm{P}, \mathrm{K}, \mathrm{Ca}$, and $\mathrm{Mg}$ ) and micronutrients ( $\mathrm{Na}, \mathrm{Fe}, \mathrm{Mn}, \mathrm{Cu}$, and $\mathrm{Zn}$ ). To do so, $0.2 \mathrm{~g}$ of leaf sample was digested using $3 \mathrm{ml}$ of nitric acid at $65 \%$ during $16 \mathrm{~h}$ at room temperature. Then the dissolution was dried up to $80{ }^{\circ} \mathrm{C}$ for $1 \mathrm{~h}$ before adding $1 \mathrm{ml}$ of perchloric acid at $60 \%$. The sample is later heat up to $180^{\circ} \mathrm{C}$ for $4 \mathrm{~h}$ until it is almost transparent. Phosphorus concentration was determined according to the molybdate blue method (Murphy and Riley, 1962). Ca and Mg were determined by atomic absorption spectrophotometry, while $\mathrm{K}$ and Na were determined by atomic emission spectrophotometry. Lastly, $\mathrm{Fe}, \mathrm{Mn}, \mathrm{Cu}$, and $\mathrm{Zn}$ were determined by atomic absorption spectrophotometry.

Additionally, two branch samples of about $5 \mathrm{~cm}$ length and $1 \mathrm{~cm}$ diameter were collected from each individual. We weighed them to calculate the branch fresh mass (in $\mathrm{g}$ ) and we calculated the branch volume using Archimedes' principle (displaced volume of water). Branch samples were dried at $60{ }^{\circ} \mathrm{C}$ for 4 days to obtain branch-wood dry mass (BWDM). Branch-wood density (BWD, $\mathrm{g} \mathrm{cm}^{-3}$ ) was calculated as BWDM/branch volume, and branch-wood dry matter content (BWDMC) was calculated as branch-wood dry mass/branch-wood fresh mass. All measured functional traits were calculated following the methodology described in Pérez-Harguindeguy et al. (2013).

\subsection{Abiotic factors}

In each plot, four random points were selected and soil samples were taken at $0-20 \mathrm{~cm}$ depth. The soil cores obtained were mixed in two independent samples. Later, the samples were dried at room temperature, ground, sieve ( $2 \mathrm{~mm}$ ), and stored in plastic closed bags. Soil texture was determined in $10 \mathrm{~g}$ of soil using the Robinson pipette method (Gee et al., 1986). Soil organic carbon was measured by the Walkley and Black (1934) method with potassium dichromate. After a partial extraction of available soil nutrients, we measured soil macronutrients ( $\mathrm{P}, \mathrm{K}, \mathrm{Ca}$, and $\mathrm{Mg}$ ) and micronutrients ( $\mathrm{Na}, \mathrm{Fe}, \mathrm{Mn}, \mathrm{Cu}$, and $\mathrm{Zn}$ ). To determine $\mathrm{P}$ content, we use the $\mathrm{NaHCO}_{3} 0.5 \mathrm{M}$ extraction (Olsen et al., 1982), and for $\mathrm{Na}, \mathrm{Ca}, \mathrm{K}$ and $\mathrm{Mg}$, soil samples were extracted by $1 \mathrm{M}$ $\mathrm{NH}_{4} \mathrm{OAc}$ at $\mathrm{pH}$ 7. $\mathrm{Fe}, \mathrm{Zn}, \mathrm{Mn}$, and $\mathrm{Cu}$ were determined after extraction 


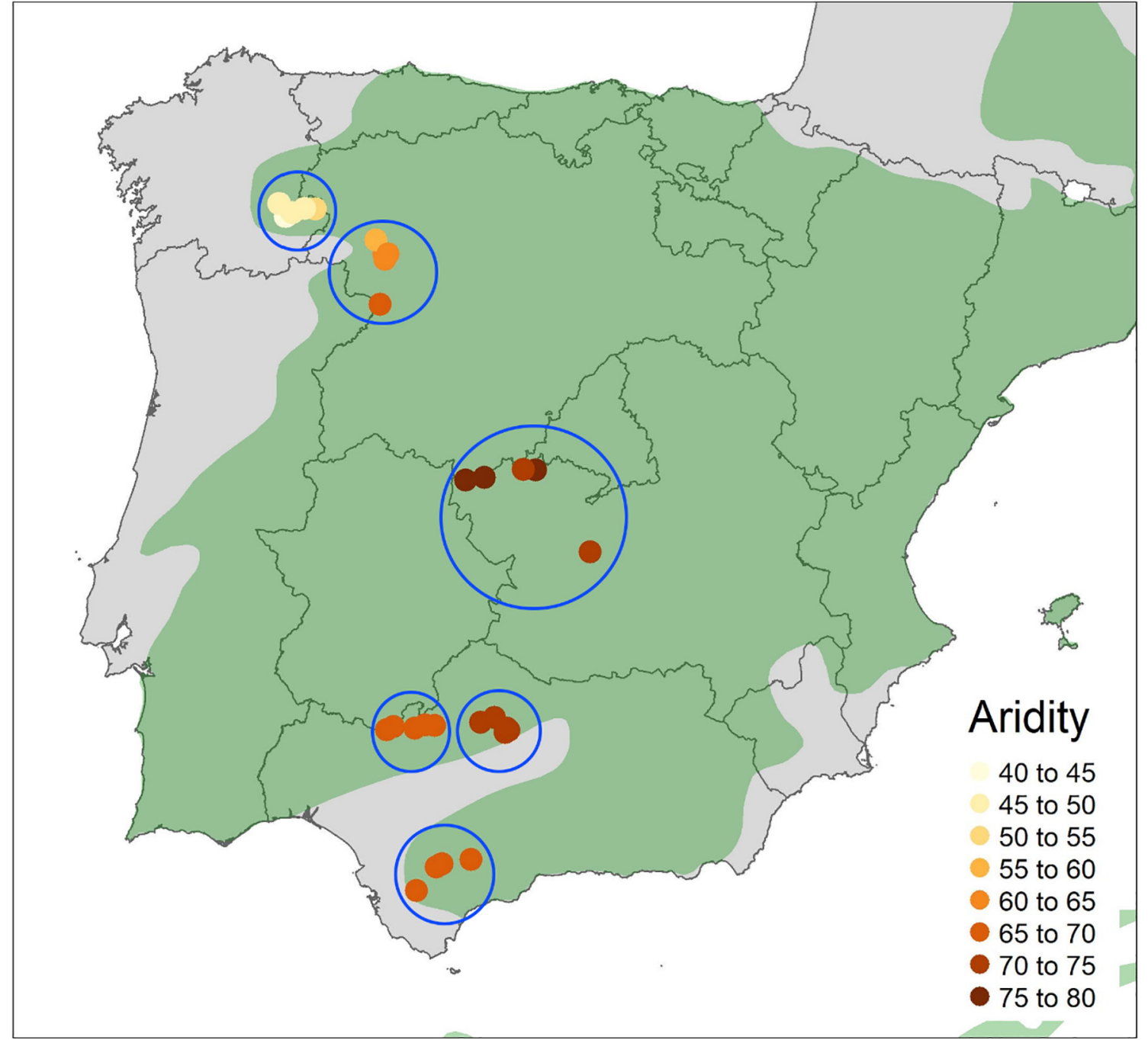

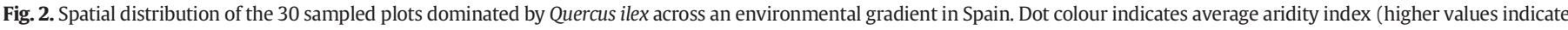
high aridity). Blue circles indicate the 6 climate regions used as random effect in the models.

Table 1

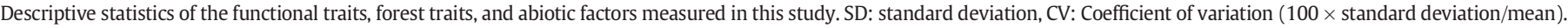

\begin{tabular}{|c|c|c|c|c|c|c|}
\hline Abr. & Variable & Mean & SD & Min & Max & $\mathrm{CV}$ \\
\hline LA & Leaf area $\left(\mathrm{cm}^{-2}\right)$ & 4.44 & 1.62 & 1.66 & 10.61 & 36.56 \\
\hline LD & Leaf density $\left(\mathrm{g} \mathrm{cm}^{-3}\right)$ & 0.53 & 0.09 & 0.29 & 0.82 & 15.92 \\
\hline LMA & Leaf mass per area $\left(\mathrm{g} \mathrm{m}^{-2}\right)$ & 216 & 36 & 115 & 321 & 16 \\
\hline LT & Leaf thickness $(\mu \mathrm{m})$ & 404 & 57 & 233 & 559 & 14 \\
\hline BWD & Branch-wood density $\left(\mathrm{g} \mathrm{cm}^{-3}\right)$ & 1.14 & 0.05 & 0.88 & 1.35 & 4.40 \\
\hline BWDMC & Branch-wood dry matter content (\%) & 61.5 & 4.9 & 51.9 & 85.7 & 8.0 \\
\hline TB & Tree biomass ( $\mathrm{kg}$ tree $^{-1}$ ) & 545 & 822 & 15 & 5754 & 151 \\
\hline $\mathrm{TD}$ & Tree density (number of trees ha ${ }^{-1}$ ) & 263 & 282 & 32 & 1273 & 107 \\
\hline FB & Forest biomass $\left(\mathrm{Mg} \mathrm{ha}^{-1}\right)$ & 37.9 & 16.7 & 8.7 & 73.1 & 44.0 \\
\hline $\mathrm{FP}$ & Forest productivity $\left(\mathrm{Mg} \mathrm{ha}^{-1}\right.$ year $\left.^{-1}\right)$ & 2.51 & 1.65 & 0.49 & 6.20 & 65.70 \\
\hline \multirow[t]{4}{*}{ RGR } & Relative growth rate $\left(\mathrm{g} \mathrm{kg}^{-1}\right.$ year $\left.^{-1}\right)$ & 48.3 & 44.6 & 0.5 & 240.9 & 92.3 \\
\hline & Clay $(\%)$ & 10.0 & 9.5 & 1.0 & 44.1 & 95.5 \\
\hline & Aspect $\left({ }^{\circ}\right)$ & 205 & 107 & 2 & 358 & 52 \\
\hline & Slope (\%) & 7.55 & 5.79 & 0.21 & 25.49 & 76.69 \\
\hline Elev & Elevation (m) & 556 & 170 & 233 & 861 & 31 \\
\hline Hills & Hillshade & 0.68 & 0.08 & 0.41 & 0.83 & 11.39 \\
\hline TPI & Topographic position index & -1.09 & 2.81 & -10.46 & 4.73 & -258.51 \\
\hline TRI & Topographic roughness index & 6.83 & 5.02 & 0.13 & 20.64 & 73.51 \\
\hline MAP & Mean annual precipitation ( $\mathrm{mm})$ & 622 & 142 & 357 & 858 & 23 \\
\hline MAT & Mean annual temperature $\left({ }^{\circ} \mathrm{C}\right)$ & 14.3 & 1.8 & 10.9 & 17.4 & 12.6 \\
\hline $\mathrm{AI}$ & Aridity index & 66.0 & 8.8 & 45.2 & 79.4 & 13.3 \\
\hline
\end{tabular}


with a solution containing $0.1 \mathrm{M}$ triethanolamine (TEA), $0.005 \mathrm{M}$ diethylenetriaminepentaacetic acid (DTPA), and $0.01 \mathrm{M} \mathrm{CaCl}_{2}$ (Norvell and Lindsay, 1972). Then, soil nutrient analysis was made using the same methodology described before for leaf nutrients.

Soil topography was also considered as an abiotic factor for this study. Digital elevation models (DEM) were downloaded as raster files using the "elevatr" package. The slope, aspect, topographic position index (TPI), terrain ruggedness index (TRI), and hillshade were calculated for all plots. The slope (\%) was calculated as the maximum change in elevation between the cell and its eight neighbor cells. The aspect was calculated as the direction of the slope in decimal degrees clockwise from the north $\left(0^{\circ}\right.$ North, $180^{\circ}$ South $)$. The TPI was calculated as the difference between the maximum and the minimum value of a cell and its eight surrounding cells. Positive TPI values represent cells that are higher than the average of their surroundings cells, while negative values represent cells that are lower than their surroundings cells. The TRI was calculated as the mean of the absolute differences between the value of a cell and the value of its eight neighbor cells. Low TRI values represent even terrain surfaces, while high TRI values (over 250) are considered rugged surfaces. The hillshade calculates the hill shade from the slope and aspect layers as a number from 0 (low sun exposure) to 1 (high sun exposure). Due to the high correlation between TPI, TRI and hillshade, with slope and aspect, we decided to exclude slope and aspect from the models.

Moreover, mean annual temperature (MAT) and precipitation data (MAP) were downloaded from the WorldClim database (Hijmans et al., 2005). Additionally, we downloaded the precipitation in the driest month (DMP) and the temperature in the driest month (DMT) in Celsius degrees to calculate the modified Martonne aridity index (Stephen, 2005) as $\mathrm{AI}_{\mathrm{m}}$ where $\mathrm{AI}_{\mathrm{m}}=\{[\mathrm{MAP}] /[\mathrm{MAT}+10]\}+\{[12 \times$ $\mathrm{DMP}] /[\mathrm{DMT}+10] / 2\}$. Since high $\mathrm{AI}_{\mathrm{m}}$ indicates high water availability, we transformed this variable as follows: $\mathrm{AI}=100-\mathrm{AI}_{\mathrm{m}}$. The transformation of $\mathrm{AI}\left(100-\mathrm{AI}_{\mathrm{m}}\right)$ is the inverse of $\mathrm{AI}_{\mathrm{m}}$, and therefore the relationship between these two variables is completely linear and did not affect the results.

\subsection{Statistical analyses}

To reduce the amount of soil nutrient variables (11 variables), a principal component analysis (PCA) for all soil nutrients (S) was carried out (Fig. S1, Supplementary Material). The main axes $\left(S_{1}\right.$ and $\left.S_{2}\right)$ explained $39.6 \%$ and $21 \%$ of the variance, respectively (Fig. S1A, Supplementary material). The axis $S_{1}$ was positively related to $\mathrm{Ca}$ and $\mathrm{N}$ concentration, while the axis $S_{2}$ was positively related to $P$ and Fe concentration (Fig. S1B, Supplementary Material). To explore the overall relationships between abiotic factors (soil and climate variables) and avoid collinearity in the models, a correlation matrix with all potential abiotic variables was performed (Fig. S2A, Supplementary Material). Due to the high correlation between MAT, MAP, and $\mathrm{AI}(P>0.05$, we exclude both MAT and MAP from further analysis.

Similarly, we carried out a PCA for the leaf nutrients (L) to reduce the number of variables (Fig. S3, Supplementary Material). In this case, the amount of variance explained, and the variable scores of the PCA were also used to analyze the leaf nutrient variability and the variables that drive the most variation in each axis. Furthermore, to explore the overall relationships between functional traits and avoid collinearity in the models, a correlation matrix was made (Fig. S2B, Supplementary Material). The LMA, LD, LA, and LT showed a tight correlation between them, while BWDMC was negatively correlated with BWD. Therefore, only LMA and BWD were included as explanatory variables.

To quantify the direct effect of abiotic factors (climate variables, topography, soil texture and nutrients) on chemical and morphological leaf traits, we carried out linear mixed-effects (LME) models for each response variable at tree level (Objective 1; Fig. 1). To explore the effect of abiotic factors (climate variables, topography, soil texture and nutrients) and functional traits on the relative growth rate, we carried out an LME model at the tree level (Objective 2; Fig. 1). All trees in our study were clustered within the plots $(n=30)$, and the plots were clustered within regions $(n=6)$. Therefore, to account for the no independence of our dataset (Lefcheck, 2021), we nested the plot random factor in the region random factor. We used the Gaussian family function to fit the models. Prior to any modeling analysis, data was scale transform using the basic "scale" function in the R software (which subtracts each data by the variable mean and divide it by the standard deviation).

Finally, to explain the causal effect of these variables on forest productivity, and account for both direct and indirect effects, we built two piecewise structural equation models (SEM) using first tree level data to explain the RGR and, second, plot-level data to explain forest productivity (Objective 3 ). The structure of the hypothesized causal relationships between the selected variables was set based on our expected relationships in Fig. 1. Since forest variables (forest productivity and forest biomass) and abiotic factors (climate variables, soil texture and nutrients, and soil topography) were only calculated at plot level and functional traits (LMA, LT, LD, BWD, BWDMC), tree biomass and RGR were calculated at tree level, we decided to split the analysis into two SEMs to avoid losing intraspecific variability data. First, we used data at the tree level to explain RGR using the results from Objectives 1 and 2. Then, mean values from the tree-level data were calculated to obtain a value of RGR and forest biomass per plot. These variables were then used in a subsequent SEM performed at the forest level to assess their effects on forest productivity. Our theoretical model was changed based on our previous results to exclude non-significant relationships as a function of the highest statistical support according to the significance of the Fisher's $C$ value $(P>0.05)$, indicating that the relationships of the missing paths are neither significant nor related to our model (Shipley, 2009). In both cases, the model was fit by maximizing the restricted log-likelihood.

Data analysis was carried out using the R statistical computing software (R Core Team, 2017). The tidyverse package was used for data manipulation and graphic display (Wickham et al., 2019). Spatial representation of the NFI was done with the package "sp" and "sf" (Pebesma, 2018). Map generation was done with the package "tmap" (Tennekes, 2018). Worldclim data was downloaded and extracted with the package "raster" (Hijmans et al., 2005). The linear mixed effect model analyses were carried out using the "lmer" package (Pinheiro et al., 2017). All the data and the script to generate these results can be accessed from an open repository in github (https://github.com/ PabloCSZ/ForChange/tree/forchange_soil).

\section{Results}

\subsection{Variation in functional traits}

Functional traits showed high variability, being particularly large for leaf area (Table 1). LMA, LD, and LT had around $14-16 \%$ coefficient of variation, and the range between minimum and maximum values was higher than the mean. BWD and BWDMC showed the lowest coefficient of variation among all variables, ranging between 4 and $8 \%$ (Table 1 ).

Leaf nutrients were summarized by the first and second principal component axes ( $L_{1}$ and $L_{2}$ ) that explained $32.7 \%$ and $20.1 \%$ of the variance, respectively (Fig. S3A, Supplementary material). The $\mathrm{L}_{1}$ axis was mainly positively related to $\mathrm{Cu}, \mathrm{Fe}$, and $\mathrm{Ca}$ concentration, while the $\mathrm{L}_{2}$ axis was positively related to $\mathrm{N}, \mathrm{P}$, and negatively to Na concentration (Fig. S3B, Supplementary Material). The intraspecific variability in leaf functional traits showed strong relationships between them and were orthogonal to those related to branch wood density (see Fig. S2B, Supplementary Material).

The variance of plant morphological traits explained in the models was between 0.52 and 0.9 (see conditional $\mathrm{R}^{2}$, Table 2 ). However, random effects account for a substantial amount of variance, in some cases, higher to the fixed effects (see marginal and conditional $\mathrm{R}^{2}$, Table 2). Aridity index was the variable with the strongest effect on 
Table 2

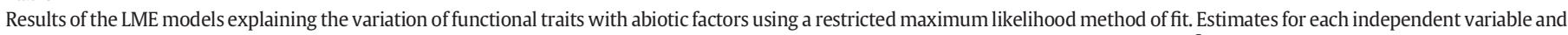

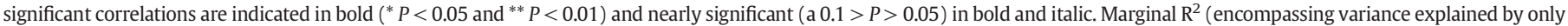
the fixed effects) and conditional $\mathrm{R}^{2}$ (comprising variance explained by both fixed and random effects). See Table 1 for acronyms.

\begin{tabular}{|c|c|c|c|c|c|c|c|c|c|}
\hline \multirow[t]{2}{*}{ Response variable } & \multicolumn{4}{|c|}{ Independent variables } & \multirow[t]{2}{*}{ Hillshade } & \multirow[t]{2}{*}{ TRI } & \multirow[t]{2}{*}{ TPI } & \multirow[t]{2}{*}{$\mathrm{R}^{2} \mathrm{M}$} & \multirow[t]{2}{*}{$\mathrm{R}^{2} \mathrm{C}$} \\
\hline & AI & S1 & S2 & Clay \% & & & & & \\
\hline LMA & $0.42^{* *}$ & -0.21 & 0.017 & 0.08 & 0.26 & -0.1 & -0.21 & 0.33 & 0.52 \\
\hline LD & -0.09 & 0.23 & -0.22 & -0.01 & -0.10 & -0.27 & -0.11 & 0.08 & 0.43 \\
\hline LT & $0.64^{* *}$ & $-0.48^{*}$ & $0.27 \mathrm{a}$ & 0.09 & $0.44^{* *}$ & 0.17 & -0.17 & 0.45 & 0.62 \\
\hline LA & -0.06 & 0.22 & -0.02 & -0.24 & -0.07 & 0.12 & 0.25 & 0.1 & 0.43 \\
\hline BWDMC & 0.40 & -0.21 & $0.28 a$ & -0.05 & 0.22 & $0.38^{*}$ & -0.08 & 0.1 & 0.43 \\
\hline BWD & -0.02 & -0.01 & -0.16 & 0.03 & 0.02 & 0.12 & $-0.28 a$ & 0.05 & 0.43 \\
\hline $\mathrm{L} 1$ & 0.21 & 0.16 & 0.09 & $0.33^{*}$ & $-0.28^{*}$ & 0.05 & 0.05 & 0.28 & 0.79 \\
\hline L2 & -0.08 & -0.02 & -0.05 & 0.12 & 0.06 & -0.04 & 0.13 & 0.03 & 0.9 \\
\hline
\end{tabular}

LMA and leaf thickness, having a positive effect on both traits (Table 2, Fig. $3 \mathrm{~A}$ and $\mathrm{B}$ ). Abiotic factors were not able to significantly explain the intraspecific variability in LD, LA, and BWD in the models. However, hillshade and soil nutrients $\left(S_{1}\right.$ and $S_{2}$ axes) showed a significant effect on leaf thickness, whereas terrain ruggedness index (TRI) showed a significant positive effect on BWDMC (Table 2). Leaf nutrients, summarized in the first principal component axes $\left(\mathrm{L}_{1}\right)$, were mainly explained by clay percentage (Fig. $3 \mathrm{C}$ and $\mathrm{D}$, respectively) and hillshade, yet the models showed a marginal $\mathrm{R}^{2}$ of 0.28 (Table 2). A high clay percentage was related to a high $\mathrm{Ca}, \mathrm{Cu}$, and Fe leaf concentration but low N, P, and Na leaf concentration. Mixed model diagnostics (residual distribution and partial residuals) showed that model assumptions were met for each case (Figs. S4, S5, and S6, Supplementary Material).

\subsection{Variation in relative growth rate $(R G R)$}

RGR showed a high coefficient of variance among trees (92.3\%), with values ranging between 0.5 to $240.9 \mathrm{~g} \mathrm{~kg}^{-1}$ year $^{-1}$ (Table 1). It was explained negatively by the soil PCA second axis and tree biomass (Fig. 4A and B, respectively). Functional traits, soil topography, and climatic factors did not show a significant effect on RGR, and the model showed a marginal $\mathrm{R}^{2}$ of 0.28 (Table 3 ).

\subsection{Forest productivity model}

The two piecewise SEM built based on our initial hypothesized model to explain RGR and forest productivity showed a high goodness of fit (Fisher's $C=28.9, P$ value $=0.15$, and Fisher's $C=8.1, P$-value
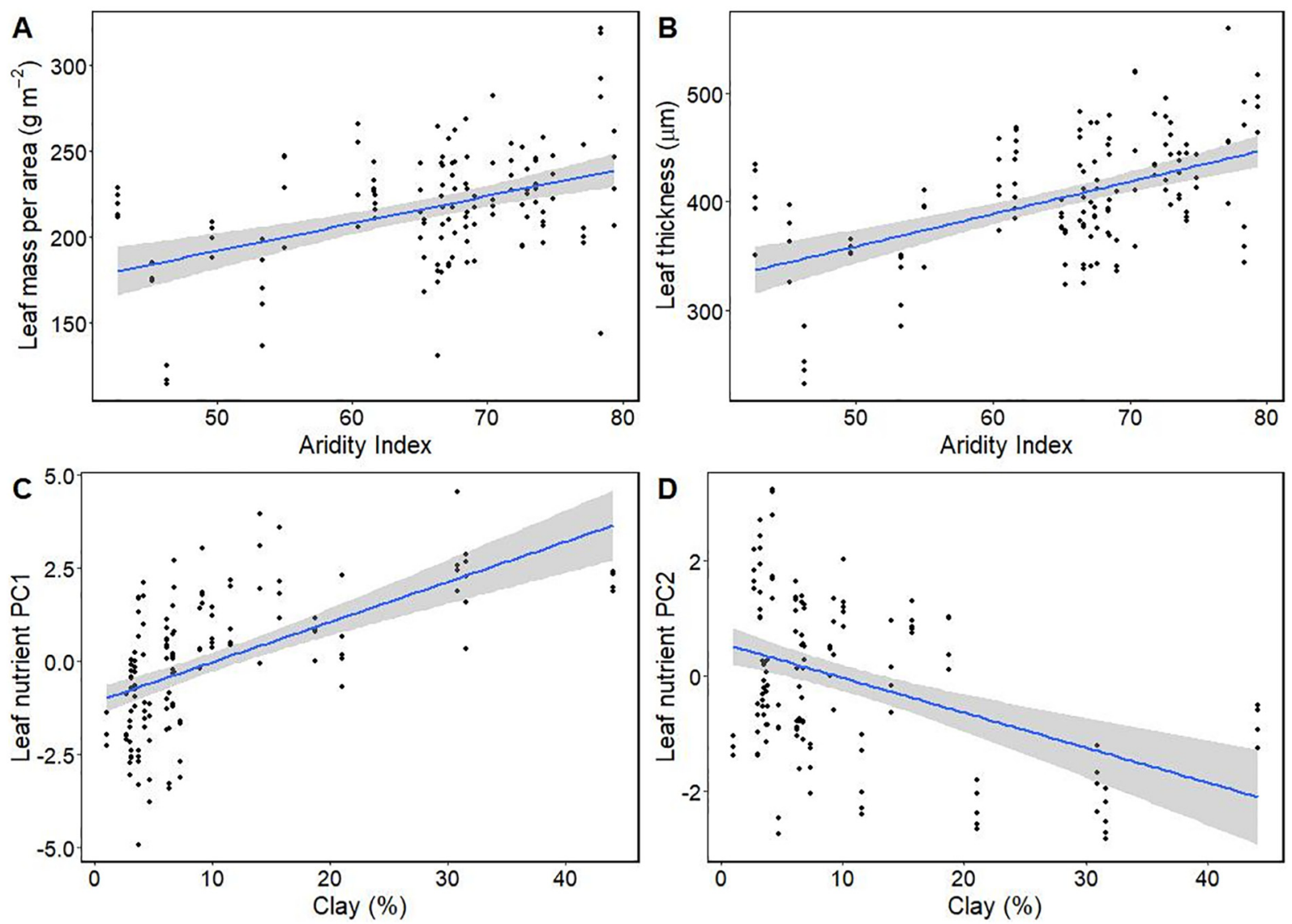

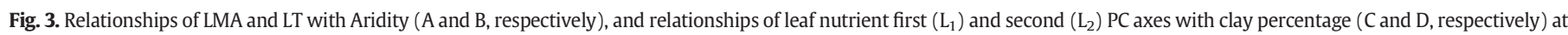
tree level. Grey area indicates 95\% confidence interval. 

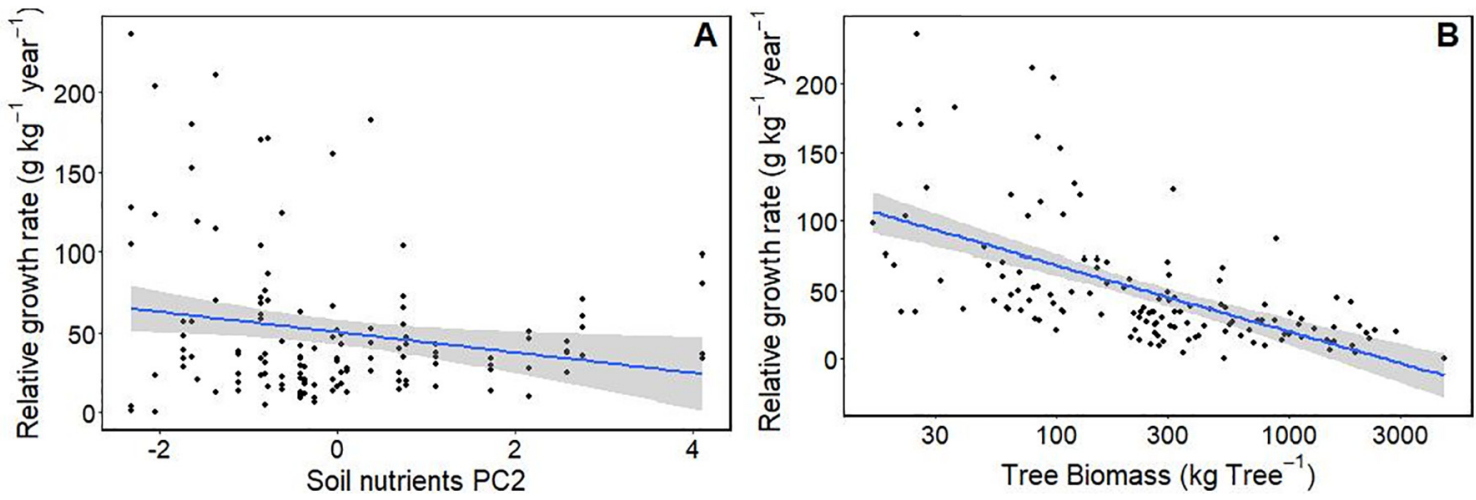

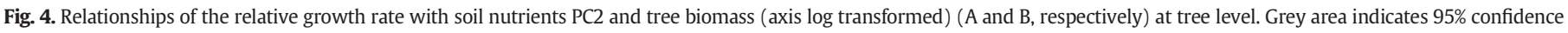
interval.

$=0.74$, respectively) and account for both direct and indirect effects of functional traits and abiotic factors. At the tree level, the soil texture and topography explained the leaf nutrients $\left(\mathrm{L}_{1}\right)$ (Fig. 5). $\mathrm{L}_{1}$ and branchwood density explained the tree biomass and together with the soil nutrients $\left(S_{1}\right.$ and $\left.S_{2}\right)$ explained the RGR of each tree. At the plot level, aridity and $\mathrm{L}_{1}$ explained the mean LMA of the plot, which alongside $\mathrm{L}_{1}$ explained the forest biomass. Ultimately, the mean RGR of the plot, and the forest biomass, explained the forest productivity (Fig. 5).

\section{Discussion}

Our results showed that forest productivity was mainly explained by RGR, which, in turn, was affected by tree biomass and soil nutrients, with an indirect effect of functional traits and climate factors. We found a positive effect of LMA and leaf nutrients on forest biomass that directly affected forest productivity. This suggests that the variability of functional traits in response to climate factors might directly affect forest carbon storage in the long run.

\section{Effects of abiotic factors on functional traits}

LMA constitutes the most measured and commonly used trait to describe plant ecological strategies. Our results indicated that LMA was positively related to aridity and sun exposure time due to the hill shade effect. Similarly, LMA has also been found to decrease with precipitation (Ogaya and Peñuelas, 2007) and temperature (Poorter et al., 2009; Vilà-Cabrera et al., 2015). Leaf thickness was also explained by aridity and hillshade and showed a high correlation with LMA. This suggests that the increase in LMA under drought conditions and high light exposure is linked with an increase in leaf thickness, associated with a larger volume of mesophyll area in the leaf tissue (Poorter et al., 2009; Villar et al., 2013). In theory, this morphological change has a direct impact on the gas exchange (Maire et al., 2015) and water transport (Rosas et al., 2019), and it may reduce the impact of abiotic stress on plant growth.

\section{Table 3}

Results of the relative growth rate (RGR) model explained by tree biomass (TB), functional traits (LMA. BWDMC), leaf nutrients main PC axes $\left(\mathrm{L}_{1}\right.$ and $\left.\mathrm{L}_{2}\right)$, soil nutrients main PC axes $\left(\mathrm{S}_{1}\right.$ and $\left.\mathrm{S}_{2}\right)$, soil texture and topography (Clay, TPI, TRI, and Hills), and aridity using a restricted maximum likelihood method of fit. Significant correlations are indicated $\left({ }^{*} P<\right.$ 0.05 and $\left.{ }^{* *} P<0.01\right)$. Marginal and conditional $\mathrm{R}^{2}$ are included. The table is displayed in two rows. See Table 1 for acronyms.

\begin{tabular}{lllllllllll}
\hline Independent variable & TB & & LMA & BWDMC & L1 & L2 & S1 & \multicolumn{2}{l}{ S2 } \\
\hline & & $-\mathbf{0 . 5 8}^{* *}$ & 0.05 & 0.07 & & 0.01 & 0.14 & $\mathbf{0 . 3 4}^{*}$ & $-\mathbf{0 . 3 9}^{* *}$ \\
\multirow{2}{*}{ Independent } & Clay & & TPI & TRI & Hills & AI & $\mathrm{R}^{2} \mathrm{M}$ & $\mathrm{R}^{2} \mathrm{C}$ \\
\hline & -0.19 & 0.02 & 0.03 & 0.04 & -0.04 & 0.28 & 0.41 \\
\hline
\end{tabular}

The leaf chemical traits were mainly explained by the clay percentage and sun exposure due to the hill shade effect, rather than aridity or soil nutrients. A high clay percentage in the soil is generally associated with low water drainage and high nutrient storage (Anderson et al., 2006). Overall, this leads to a high soil nutrients availability (Table S1, Supplementary material), and ultimately, a high leaf nutrient concentration. However, for some nutrients, a high clay percentage associated with a high concentration of iron oxide can also lead to a more negative soil matric potential in summer and autumn and reduce soil nutrient transport, a situation referred to as the inverse texture effect (Fernandez-Illescas et al., 2001). This might be our case based on the negative correlation between clay percentage and the $L_{2}$ axis (mainly explained by the leaf $\mathrm{N}$ and $\mathrm{P}$ concentration), and the negative effect of clay percentage on soil P concentration (data not shown). Furthermore, an increase in leaf $P$ concentration seems to be paired up with high leaf Mn concentration (Fig. S1, Supplementary material). The accumulation of $\mathrm{Mn}$ in the leaf is relatively common when P mobility in the soil is limited (Lambers et al., 2015). It seems that root exudates can locally modify the soil pH, which makes P more available alongside Mn (White et al., 2013). Therefore, it is possible that the clay percentage in the soil can increase soil nutrients concentration, but reducing its mobility in highly demanded nutrients, like $P$. The increase in sun exposure due to the hillshade effect can lead to oxidative stress and damage the parenchymal tissue despite the increase in leaf thickness (DemmigAdams and Adams, 2006). This would reduce photosynthetic rate and leaf nutrients mimicking water stress in arid conditions. Thus, our results highlight the importance of soil texture and topography to shape the leaf chemical composition. However, the random effects associated to the location of the plots explain a large portion of the variation in functional traits. Therefore, it is possible that other biotic or abiotic factors play a key role in plant functioning at a regional scale.

\subsection{Effect of abiotic factors, functional traits, and forest structure on RGR}

The individual tree biomass was the main intrinsic factor explaining the RGR of the trees. This negative relationship suggests that larger trees tend to grow more slowly, which could be explained by a lower proportion of leaves (Villar et al., 2017). Thus, as the tree biomass and the number of resources required for growing increase, nutrient assimilation and transport proportionally decrease, reducing RGR. Competitive interactions for light and nutrients between surrounding trees reduce plant growth, at least in the early years (Binkley, 2004). Thus, the magnitude of the biomass-growth relationship depends also on the competitive environment (Ruiz-Benito et al., 2015). Furthermore, hydraulic and nutrient limitations appear in older trees due to mechanical constraints in vessel size, which reduces both water and nutrient transport (Mencuccini et al., 2005). An increase in soil nutrient concentration should yield high plant biomass, however, this only seems to be true for small trees ( $\mathrm{Li}$ et al., 2018). The increase in soil 


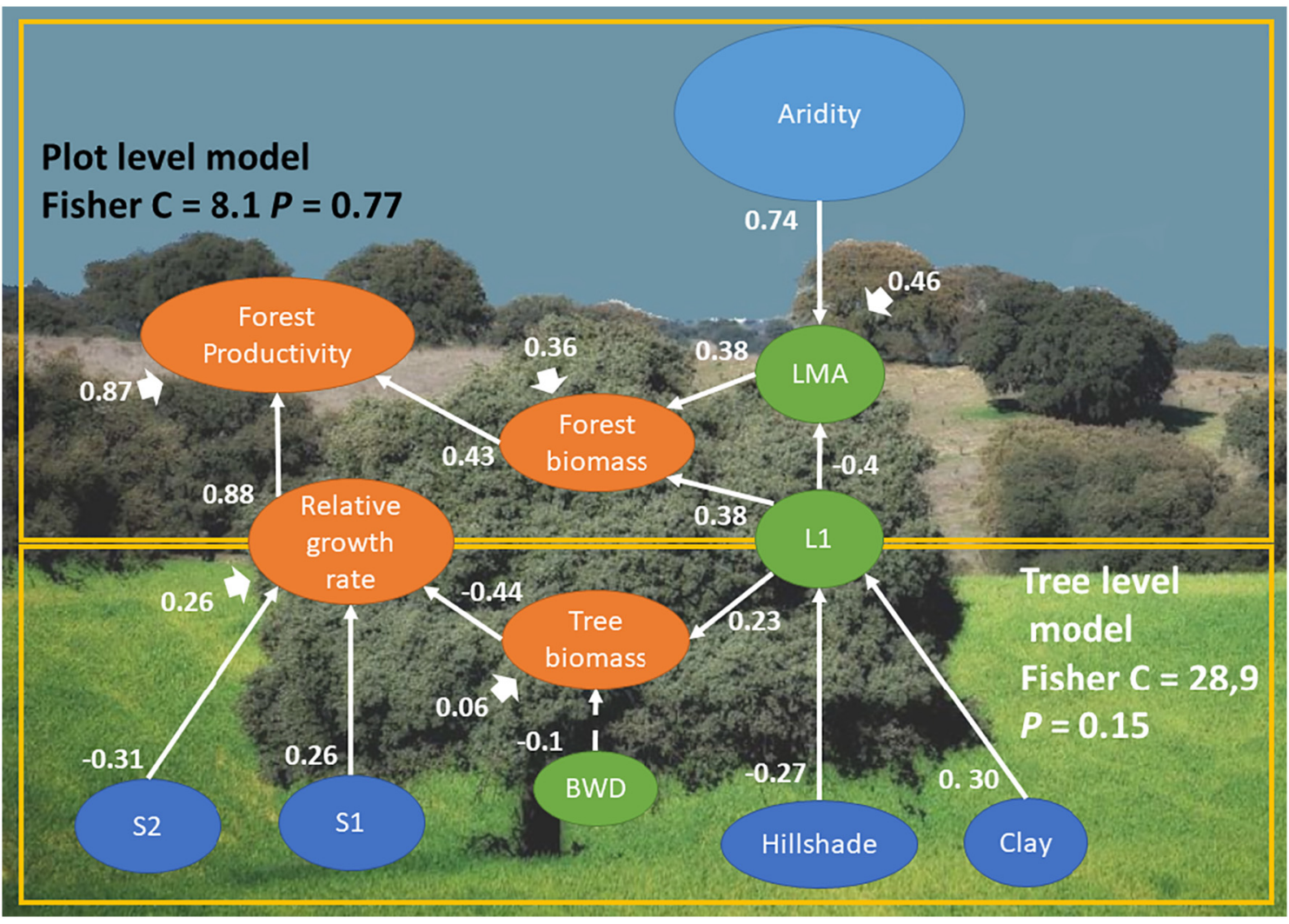

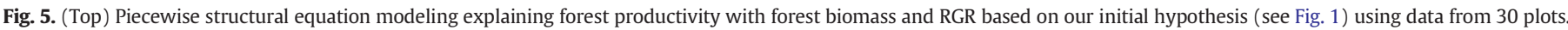

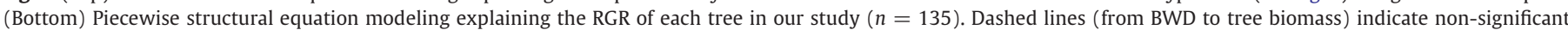

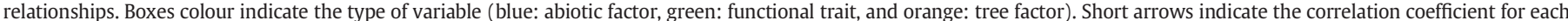
response variable $(n=135)$. $S_{1}$ and $S_{2}$ (first and second axes of soil PCA), LMA (leaf mass per area), $L_{1}$ and $L_{2}$ (first and second axes of leaf PCA), BWD (branch-wood density).

nutrients concentration does not mitigate the morphological changes associated with nutrient transport when the tree gets older and the biomass increases (Drake et al., 2010). In our case, RGR was explained by the soil nutrients summarized in the soil PCA axes $\left(\mathrm{S}_{1}\right.$ and $\left.\mathrm{S}_{2}\right)$. However, opposite results have also been found (Paoli and Curran, 2007; Zemunik et al., 2018), and further studies are still required to understand the effect of soil nutrients on plant growth under field conditions.

Climate factors had a low effect on RGR, in agreement with previous results for several Quercus species suggesting a lower explanatory power of climate in comparison to local factors as nutrient availability, soil texture, and tree density (Villar et al., 2017). Furthermore, functional traits did not show a significant effect on RGR either, which contradicts several studies that suggested functional trait variability has a physiological impact at the whole-plant level (Poorter et al., 2009; Violle et al., 2007). However, most of those studies have been performed in young seedlings rather than adult trees (Bastias et al., 2018). When this distinction has been made, results have shown that LMA does not correlate with RGR for adult trees (Laughlin et al., 2017; Wright et al., 2010). The lack of relationship has been justified by the absence of a clear physiological basis in the so-called "soft traits", like LMA and leaf thickness, and tree height (Rosas et al., 2019). However, this kind of terminology has been questioned because it focuses on methodological aspects (how easy or difficult it is to measure a certain trait) and underestimates the functional meaning of leaf morphology (Violle et al., 2007). In Q. ilex evergreen leaves, high LMA is the result of high sclerenchymatic tissues (de la Riva et al., 2016b) that confer leaf resistance to water diffusion from the vein to the mesophyll during climatic stress. Most likely, the leaf functional trait plasticity is reducing the negative effect of environmental stress, thus, limiting the reduction of RGR
(Gratani, 2014). According to this, morphological changes in the leaf are made to keep plant growth steady regardless of climate conditions.

\subsection{Modeling forest productivity depending on ecological, physiological,} and environmental factors

Our models confirm our initial hypothesis, which suggests that forest productivity depends on both RGR and forest biomass. Key functional traits like LMA and BWD affect forest productivity, but not directly as we initially hypothesized. For instance, the effect of LMA and climatic factors (i.e. aridity) over RGR did not occur directly, instead, increases of LMA directly affect tree biomass (Antúnez et al., 2001; Lambers and Poorter, 2004). However, this relationship does not hold itself when the tree size increases because respiratory losses for maintenance increases in large trees (Mencuccini et al., 2005). Thus, even though LMA is a highly sensitive trait to environmental factors, its variation does not always represent an adaptive advantage to increase the RGR. Instead, we found a positive effect of LMA on forest biomass. This suggests that a thick and dense leaf increases forest biomass in the long term. Similar results have been found when limited conditions are present (van der Sande et al., 2018), and in temperate forests (Yuan et al., 2019). Similarly, other abiotic factors, such as soil topography and texture, showed an indirect effect on tree biomass by affecting leaf nutrient concentration. Therefore, leaf chemical and morpho-physiological changes might be a strategy to maintain water transport, leaf nutrition, and C uptake under abiotic stress, therefore increasing the forest biomass.

The positive effect of intraspecific trait variability on tree biomass and tree growth could be potentially occurring in other $Q$. ilex forests, which are well distributed across the South of Europe and around the Mediterranean basin (Urbieta et al., 2011) or even for other tree species. 
The specific effect of abiotic factors on functional traits and plant growth should be further explored in other Mediterranean ecosystems in South America, Southwest Australia or South Africa where summer aridity can have a detrimental effect on species distribution and functional diversity (Christie et al., 2011; Gil-Pelegrín and Peguero-Pina, 2017). The intraspecific variability of leaf traits, such as LMA, are related to their adaptation to xeric conditions (Gil-pelegrín and Peguero-Pina, 2017), and should influence forest demographic characteristics across the globe. Here, we focused our analysis on tree growth and forest productivity but other key demographic processes as tree mortality and regeneration are critical determining long-term forest dynamics (e.g. Astigarraga et al., 2020; Lines et al., 2020). Furthermore, differential demographic responses can alter population density and the diversity in functional traits affecting to plant-plant competition and forest productivity (Beckage and Clark, 2003; Gillner et al., 2013). Ultimately, our study showed that forest productivity is mainly explained by RGR, which is affected by tree biomass and soil nutrients. This result suggests that protecting established forests increases forest biomass, and utterly, forest productivity (Morán-Ordóñez et al., 2020). Scheduling pruning and wood harvesting allow for a reduction in stand density, increase light availability in dense patches, and eliminate competitive interactions between trees (Reyes et al., 2008). Similarly, protecting species diversity and regulating animal foraging increase soil fertility in the long term (Ammer, 2019; James et al., 2009). Thus, the implementation of regional forest policies may be as important as national environmental regulations to protect $Q$. ilex forest productivity (Mokany et al., 2008).

\section{Conclusion}

Our findings highlight that the large intraspecific variation in key functional traits (i.e. LMA) was associated with a climatic gradient and shows that plant changes to abiotic stress do not always have direct effects on plant growth or forest productivity, but indirect effects can be important. Instead, soil fertility and tree biomass have a fundamental effect on the relative growth rate, suggesting forest management may have a bigger role than we originally thought to maintain forest ecosystem services.

\section{CRediT authorship contribution statement}

Pablo Salazar Zarzosa: Formal analysis, Software, Writing - original draft. Aurelio Diaz Herraiz: Writing - review \& editing, Data curation, Investigation. Manuel Olmo: Conceptualization, Data curation, Investigation. Paloma Ruiz-Benito: Conceptualization, Methodology, Writing - review \& editing, Validation. Vidal Barrón: Methodology, Supervision. Cristina C. Bastias: Writing - review \& editing, Methodology. Enrique G. de la Riva: Conceptualization, Writing - review \& editing. Rafael Villar: Conceptualization, Writing - review \& editing, Funding acquisition, Methodology.

\section{Declaration of competing interest}

The authors declare that they have no known competing financial interests or personal relationships that could have appeared to influence the work reported in this paper.

\section{Acknowledgements}

Financial support was provided by the project Ecología funcional de los bosques andaluces y predicciones sobre sus cambios futuros (ForChange) (UCO-FEDER 18 REF 27943 MOD B), the project Funcionalidad y servicios ecosistémicos de los bosques andaluces y normarroquíes: relaciones con la diversidad vegetal y edáfica ante el cambio climático (P18-RT-3455) from Junta de Andalucía (Spain), by the Spanish MEC project DIVERBOS (CGL2011-30285-C02-02) and ECO-MEDIT (CGL2014-53236-R) and FEDER funds. We thank the MAPA (Ministerio de Agricultura, Pesca y Alimentación) and MITECO (Ministerio de Transición Ecológica) the access and the open-access availability of the Spanish Forest Inventory (https://www.mapa.gob.es/). CCB is supported by a postdoctoral fellowship of the Ramón Areces Foundation. PRB was supported by the Community of Madrid Region under the framework of the multi-year Agreement with the University of Alcalá (Stimulus to Excellence for Permanent University Professors, EPU-INV/ 2020/010). Graphical abstract background has been designed using resources from Freepik.com.

\section{Appendix A. Supplementary data}

Supplementary data to this article can be found online at https://doi. org/10.1016/j.scitotenv.2021.147468.

\section{References}

Ammer, C., 2019. Diversity and forest productivity in a changing climate. New Phytol. 221, 50-66. https://doi.org/10.1111/nph.15263.

Anderson, T.M., Dong, Y., Mcnaughton, S.J., 2006. Nutrient acquisition and physiological responses of dominant Serengeti grasses to variation in soil texture and grazing. J. Ecol. 94, 1164-1175. https://doi.org/10.1111/j.1365-2745.2006.01148.x.

Antúnez, I., Retamosa, E.C., Villar, R., 2001. Relative growth rate in phylogenetically related deciduous and evergreen woody species. Oecologia 128, 172-180. https://doi. org/10.1007/s004420100645.

Aranda, I., Pardo, F., Gil, L., Pardos, J., 2004. Anatomical basis of the change in leaf mass per area and nitrogen investment with relative irradiance within the canopy of eight temperate tree species. Acta Oecol. 25, 187-195. https://doi.org/10.1016/j. actao.2004.01.003.

Astigarraga, J., Andivia, E., Zavala, M.A., Gazol, A., Cruz-Alonso, V., Vicente-Serrano, S.M., Ruiz-Benito, P., 2020. Evidence of non-stationary relationships between climate and forest responses: increased sensitivity to climate change in Iberian forests. Glob. Chang. Biol. 26, 5063-5076. https://doi.org/10.1111/gcb.15198.

Barbero, M., Loisel, R., Quézel, P., 1992. Biogeography, ecology and history of Mediterranean Quercus ilex ecosystems, in: Romane, F., Terradas, J. (Eds.), Quercus ilex L. Ecosystems: Function, Dynamics and Management. Springer Netherlands, Dordrecht, pp. 19-34. doi:https://doi.org/10.1007/978-94-017-2836-2_2.

Bastias, C.C., Fortunel, C., Valladares, F., Baraloto, C., Benavides, R., Cornwell, W., Markesteijn, L., De Oliveira, A.A., Sansevero, J.B.B., Vaz, M.C., Kraft, N.J.B., 2017. Intraspecific leaf trait variability along a boreal-to-tropical community diversity gradient. PLoS One 12,1-16. https://doi.org/10.1371/journal.pone.0172495.

Bastias, C.C., Valladares, F., Ricote, M., Benavides, R., 2018. Local canopy diversity does not influence phenotypic expression and plasticity of tree seedlings exposed to different resource availabilities. Environ. Exp. Bot. 156, 38-47. https://doi.org/10.1016/j. envexpbot.2018.08.023

Beckage, B., Clark, J.S., 2003. Seedling survival and growth of three forest tree species: the role of spatial heterogeneity. Ecology 84, 1849-1861. https://doi.org/10.1890/00129658(2003)084[1849:SSAGOT]2.0.CO;2.

Binkley, D., 2004. A hypothesis about the interaction of tree dominance and stand production through stand development. For. Ecol. Manag. 190, 265-271. https://doi.org/ 10.1016/j.foreco.2003.10.018.

Bu, W., Huang, J., Xu, H., Zang, R., Ding, Y., Li, Y., Lin, M., Wang, J., Zhang, C., 2019. Plant functional traits are the mediators in regulating effects of abiotic site conditions on aboveground carbon stock-evidence from a 30 ha tropical forest plot. Front. Plant Sci. 9, 1-10. https://doi.org/10.3389/fpls.2018.01958.

Caudullo, G., Welk, E., San-Miguel-Ayanz, J., 2017. Chorological maps for the main European woody species. Data Br. 12, 662-666. https://doi.org/10.1016/j. dib.2017.05.007.

Chaturvedi, R.K., Raghubanshi, A.S., Singh, J.S., 2011. Leaf attributes and tree growth in a tropical dry forest. J. Veg. Sci. 22, 917-931. https://doi.org/10.1111/j.16541103.2011.01299.x.

Chave, J., Coomes, D., Jansen, S., Lewis, S.L., Swenson, N.G., Zanne, A.E., 2009. Towards a worldwide wood economics spectrum. Ecol. Lett. 12, 351-366. https://doi.org/ 10.1111/j.1461-0248.2009.01285.x.

Christie, D.A., Boninsegna, J.A., Cleaveland, M.K., Lara, A., Le Quesne, C., Morales, M.S., Mudelsee, M., Stahle, D.W., Villalba, R., 2011. Aridity changes in the temperateMediterranean transition of the Andes since ad 1346 reconstructed from tree-rings. Clim. Dyn. 36, 1505-1521. https://doi.org/10.1007/s00382-009-0723-4.

Cornelissen, J.H.C., Thompson, K., 1997. Functional leaf attributes predict litter decomposition rate in herbaceous plants. New Phytol. 135, 109-114. https://doi.org/10.1046/ j.1469-8137.1997.00628.x.

Demmig-Adams, B., Adams, W.W., 2006. Photoprotection in an ecological context: the remarkable complexity of thermal energy dissipation. New Phytol. 172, 11-21. https:// doi.org/10.1111/j.1469-8137.2006.01835.x.

Dong, N., Prentice, I.C., Wright, I.J., Evans, B.J., Togashi, H.F., Caddy-Retalic, S., McInerney, F.A., Sparrow, B., Leitch, E., Lowe, A.J., 2020. Components of leaf-trait variation along environmental gradients. New Phytol. https://doi.org/10.1111/nph.16558.

Drake, J.E., Raetz, L.M., Davis, S.C., Delucia, E.H., 2010. Hydraulic limitation not declining nitrogen availability causes the age-related photosynthetic decline in loblolly pine (Pinus taeda L.). Plant Cell Environ. 33, 1756-1766. https://doi.org/10.1111/j.13653040.2010.02180.x. 
Fajardo, A., Siefert, A., 2016. Phenological variation of leaf functional traits within species. Oecologia 180, 951-959. https://doi.org/10.1007/s00442-016-3545-1.

Fernandez-Illescas, C.P., Porporato, A., Laio, F., Rodriguez-Iturbe, I., 2001. The ecohydrological role of soil texture in a water-limited ecosystem. Water Resour. Res. 37, 2863-2872. https://doi.org/10.1029/2000WR000121.

Flexas, J., Diaz-Espejo, a., Gago, J., Gallé, a., Galmés, J., Gulías, J., Medrano, H., 2014. Photosynthetic limitations in Mediterranean plants: a review. Environ. Exp. Bot. 103, 12-23. https://doi.org/10.1016/j.envexpbot.2013.09.002.

Gee, G.W., Bauder, J.W., Klute, A., 1986. Particle-Size Analysis, Methods of Soil Analysis. Part 1. Physical and Mineralogical Methods. Soil Since Society of America. Inc, Madison, WIS, USA.

Gibert, A., Gray, E.F., Westoby, M., Wright, I.J., Falster, D.S., 2016. On the link between functional traits and growth rate: meta-analysis shows effects change with plant size, as predicted. J. Ecol. 104, 1488-1503. https://doi.org/10.1111/1365-2745.12594.

Gillner, S., Rüger, N., Roloff, A., Berger, U., 2013. Low relative growth rates predict future mortality of common beech (Fagus sylvatica L.). For. Ecol. Manag. 302, 372-378. https://doi.org/10.1016/j.foreco.2013.03.032.

Gil-pelegrín, E., Peguero-Pina, J.J., 2017. Oaks Physiological Ecology. Exploring the Functional Diversity of Genus Quercus L., Tree Physiology. Springer International Publishing, Cham https://doi.org/10.1007/978-3-319-69099-5.

Gratani, L., 2014. Plant phenotypic plasticity in response to environmental factors. Adv. Bot. 2014, 17. https://doi.org/10.1155/2014/208747.

Gratani, L., Crescente, M.F., Petruzzi, M., 2000. Relationship between leaf life-span and photosynthetic activity of Quercus ilex in polluted urban areas (Rome). Environ. Pollut. 110, 19-28. https://doi.org/10.1016/S0269-7491(99)00285-7.

Hijmans, R.J., Cameron, S.E., Parra, J.L., Jones, P.G., Jarvis, A., 2005. Very high resolution interpolated climate surfaces for global land areas. Int. J. Climatol. 25, 1965-1978. https://doi.org/10.1002/joc.1276.

James, A.I., Eldridge, D.J., Hill, B.M., 2009. Foraging animals create fertile patches in an Australian desert shrubland. Ecography 32, 723-732. https://doi.org/10.1111/ j.1600-0587.2009.05450.x.

Kunstler, G., Falster, D., Coomes, D.A., Hui, F., Kooyman, R.M., Laughlin, D.C., Poorter, L., Vanderwel, M., Vieilledent, G., Wright, S.J., Aiba, M., Baraloto, C., Caspersen, J., Cornelissen, J.H.C., Gourlet-Fleury, S., Hanewinkel, M., Herault, B., Kattge, J., Kurokawa, H., Onoda, Y., Peñuelas, J., Poorter, H., Uriarte, M., Richardson, S., RuizBenito, P., Sun, I.F., Ståhl, G., Swenson, N.G., Thompson, J., Westerlund, B., Wirth, C., Zavala, M.A., Zeng, H., Zimmerman, J.K., Zimmermann, N.E., Westoby, M., 2016. Plant functional traits have globally consistent effects on competition. Nature 529, 204-207. https://doi.org/10.1038/nature16476.

Lambers, H., Poorter, H., 2004. Inherent variation in growth rate between higher plants: a search for physiological causes and ecological consequences. Adv. Ecol. Res. 34, 284-319. https://doi.org/10.1016/S0065-2504(03)34004-8.

Lambers, H., Chapin, F.S., Pons, T.L., 2008. Plant Physiological Ecology. Springer, New York, New York, NY https://doi.org/10.1007/978-0-387-78341-3.

Lambers, H., Hayes, P.E., Laliberté, E., Oliveira, R.S., Turner, B.L., 2015. Leaf manganese accumulation and phosphorus-acquisition efficiency. Trends Plant Sci. 20, 83-90. https://doi.org/10.1016/j.tplants.2014.10.007.

Laughlin, D.C., Lusk, C.H., Bellingham, P.J., Burslem, D.F.R.P., Simpson, A.H., Kramer-Walter, K.R., 2017. Intraspecific trait variation can weaken interspecific trait correlations when assessing the whole-plant economic spectrum. Ecol. Evol. 7, 8936-8949. https://doi.org/10.1002/ece3.3447.

Lavorel, S., McIntyre, S., Landsberg, J., Forbes, T.D.A., 1997. Plant functional classifications: from general groups to specific groups based on response to disturbance. Trends Ecol. Evol. 12, 474-478. https://doi.org/10.1016/S0169-5347(97)01219-6.

Lefcheck, J., 2021. Structural Equation Modelling in R for Ecology and Evolution. [WWW Document]. URL https://jslefche.github.io/sem_book/local-estimation.html\#modelfitting-using-piecewisesem (accessed 2.26.21).

Li, Y., Tian, D., Yang, H., Niu, S., 2018. Size-dependent nutrient limitation of tree growth from subtropical to cold temperate forests. Funct. Ecol. 32, 95-105. https://doi.org/ 10.1111/1365-2435.12975.

Lines, E.R., Zavala, M.A., Ruiz-Benito, P., Coomes, D.A., 2020. Capturing juvenile tree dynamics from count data using approximate Bayesian computation. Ecography 43, 406-418. https://doi.org/10.1111/ecog.04824.

Maire, V., Wright, I., Prentice, C., Batjes, N., Bhaskar, R., Bodegom, P.M. van, Cornwell, W., Ellsworth, D., Niinemets, Ü., Ordonez, A., Reich, P.B., Santiago, L.S., 2015. Global effects of soil and climate on leaf photosynthetic traits and rates. Glob. Ecol. Biogeogr. 167, 77-93. https://doi.org/10.1007/s10681-008-9863-6.

Mencuccini, M., Martínez-Vilalta, J., Vanderklein, D., Hamid, H.A., Korakaki, E., Lee, S., Michiels, B., 2005. Size-mediated ageing reduces vigour in trees. Ecol. Lett. 8, 1183-1190. https://doi.org/10.1111/j.1461-0248.2005.00819.x.

Mokany, K., Ash, J., Roxburgh, S., 2008. Functional identity is more important than diversity in influencing ecosystem processes in a temperate native grassland. J. Ecol. 96, 884-893. https://doi.org/10.1111/j.1365-2745.2008.01395.x.

Moore, T.E., Jones, C.S., Chong, C., Schlichting, C.D., 2020. Impact of rainfall seasonality on intraspecific trait variation in a shrub from a Mediterranean climate. Funct. Ecol. 34, 865-876. https://doi.org/10.1111/1365-2435.13533.

Morán-Ordóñez, A., Ameztegui, A., De Cáceres, M., de-Miguel, S., Lefèvre, F., Brotons, L., Coll, L., 2020. Future trade-offs and synergies among ecosystem services in Mediterranean forests under global change scenarios. Ecosyst. Serv. 45, 101174. https://doi. org/10.1016/j.ecoser.2020.101174.

Murphy, J., Riley, J., 1962. A modified single solution method for the determrnation of phosphate in natural waters. Anal. Chem. ACTA 27, 31-36. https://doi.org/10.1016/ S0003-2670(00)88444-5.

Norvell, W.A., Lindsay, W.L., 1972. Reactions of DTPA chelates of iron, zinc, copper, and manganese with soils. Soil Sci. Soc. Am. J. 36, 778-783.
Ogaya, R., Peñuelas, J., 2007. Leaf mass per area ratio in Quercus ilex leaves under a wide range of climatic conditions. The importance of low temperatures. Acta Oecol. 31, 168-173. https://doi.org/10.1016/j.actao.2006.07.004.

Olsen, S.R., Sommers, L.E., Page, A.L., 1982. Methods of soil analysis. Part 2. Chem. Microbiol. Prop. Phosphorus. ASA Monogr. 403-430.

Paoli, G.D., Curran, L.M., 2007. Soil nutrients limit fine litter production and tree growth in mature lowland forest of southwestern Borneo. Ecosystems 10, 503-518. https://doi. org/10.1007/s10021-007-9042-y.

Pebesma, E., 2018. Simple features for R: standardized support for spatial vector data. R J. $10,439-446$.

Pérez-Harguindeguy, N., Diaz, S., Garnier, E., Lavorel, S., Poorter, H., Jaureguiberry, P., BretHarte, M.S.S., Cornwell, W.K.K., Craine, J.M.M., Gurvich, D.E.E., Urcelay, C., Veneklaas, E.J.J., Reich, P.B.B., Poorter, L., Wright, I.J.J., Etc, Ray, Etc, P., Díaz, S., Lavorel, S., Poorter, H., Jaureguiberry, P., Bret-Harte, M.S.S., Cornwell, W.K.K., Craine, J.M.M. Gurvich, D.E.E., Urcelay, C., Veneklaas, E.J.J., Reich, P.B.B., Poorter, L., Wright, I.J.J., Ray, P., Enrico, L., Pausas, J.G., Vos, A.C. de, Buchmann, N., Funes, G., Quétier, F., Hodgson, J.G., Thompson, K., Morgan, H.D., Steege, H. ter, Heijden, M.G.A. van der, Sack, L., Blonder, B., Poschlod, P., Vaieretti, M.V., Conti, G., Staver, A.C., Aquino, S., Cornelissen, J.H.C., 2013. New handbook for standardized measurment of plant functional traits worldwide. Aust. J. Bot. 61, 167-234. https://doi.org/10.1071/BT12225.

Pinheiro, J., Bates, D., DebRoy, S., Sarkar, D., R Core Team, 2017. nlme: Linear and Nonlinear Mixed Effects Models.

Pommerening, A., Muszta, A., 2015. Methods of modelling relative growth rate. For. Ecosyst. 2. https://doi.org/10.1186/s40663-015-0029-4.

Poorter, H., Niinemets, U., Poorter, L., Wright, I.J., Villar, R., 2009. Causes and consequences of variation in leaf mass per area (LMA): a meta-analysis. New Phytol. 182, 565-588.

Quero, J.L., Villar, R., Marañón, T., Zamora, R., 2006. Interactions of drought and shade effects on seedlings of four Quercus species: physiological and structural leaf responses. New Phytol. 170, 819-834. https://doi.org/10.1111/j.1469-8137.2006.01713.x.

Quero, J.L., Sterck, F.J., Martínez-Vilalta, J., Villar, R., 2011. Water-use strategies of six coexisting Mediterranean woody species during a summer drought. Oecologia 166 , 45-57. https://doi.org/10.1007/s00442-011-1922-3.

R Core Team, 2017. R: A Language and Environment for Statistical Computing.

Reyes, J.L., Campos, F., Wei, H., Arora, R., Yang, Y., Karlson, D.T., Covarrubias, A.A., 2008. Functional dissection of Hydrophilins during in vitro freeze protection. Plant Cell Environ. 31, 1781-1790. https://doi.org/10.1111/j.1365-3040.2008.01879.x.

de la Riva, Enrique, G., Olmo, M., Poorter, H., Ubera, J.L., Villar, R., 2016a. Leaf mass per area (LMA) and its relationship with leaf structure and anatomy in 34 mediterranean woody species along a water availability gradient. PLoS One 11,1-18. https://doi. org/10.1371/journal.pone.0148788.

de la Riva, Enrique, G., Tosto, A., Pérez-Ramos, I.M., Navarro-Fernández, C.M., Olmo, M., Anten, N.P.R., Marañón, T., Villar, R., 2016b. A plant economics spectrum in Mediterranean forests along environmental gradients: is there coordination among leaf, stem and root traits? J. Veg. Sci. 27, 187-199. https://doi.org/10.1111/jvs.12341.

Rosas, T., Mencuccini, M., Barba, J., Cochard, H., Saura-Mas, S., Martínez-Vilalta, J., 2019. Adjustments and coordination of hydraulic, leaf and stem traits along a water availability gradient. New Phytol. 223, 632-646. https://doi.org/10.1111/nph.15684.

Ruiz-Benito, P., Gómez-Aparicio, L., Paquette, A., Messier, C., Kattge, J., Zavala, M.A., 2014. Diversity increases carbon storage and tree productivity in Spanish forests. Glob. Ecol. Biogeogr. 23, 311-322. https://doi.org/10.1111/geb.12126.

Ruiz-Benito, P., Madrigal-González, J., Young, S., Mercatoris, P., Cavin, L., Huang, T.J., Chen, J.C., Jump, A.S., 2015. Climatic stress during stand development alters the sign and magnitude of age-related growth responses in a subtropical mountain pine. PLoS One 10, 1-18. https://doi.org/10.1371/journal.pone.0126581.

Ruiz-Benito, P., Ratcliffe, S., Jump, A.S., Gómez-Aparicio, L., Madrigal-González, J., Wirth, C., Kändler, G., Lehtonen, A., Dahlgren, J., Kattge, J., Zavala, M.A., 2017. Functional diversity underlies demographic responses to environmental variation in European forests. Glob. Ecol. Biogeogr. 26, 128-141. https://doi.org/10.1111/geb.12515.

Ruiz-Peinado, R., Del Rio, M., Montero, G., 2011. New models for estimating the carbon sink capacity of Spanish softwood species. For. Syst. 20, 176. https://doi.org/ 10.5424/fs/2011201-11643.

Sade, N., Gebremedhin, A., Moshelion, M., 2012. Risk-taking plants doi:https://doi.org/ 10.4161/psb.20505.

Salgado-Luarte, C., Gianoli, E., 2017. Shade tolerance and herbivory are associated with RGR of tree species via different functional traits. Plant Biol. 19, 413-419. https:// doi.org/10.1111/plb.12534.

van der Sande, M.T., Arets, E.J.M.M., Peña-Claros, M., Hoosbeek, M.R., Cáceres-Siani, Y., van der Hout, P., Poorter, L., 2018. Soil fertility and species traits, but not diversity, drive productivity and biomass stocks in a Guyanese tropical rainforest. Funct. Ecol. 32, 461-474. https://doi.org/10.1111/1365-2435.12968.

Shipley, B., 2009. Confirmatory path analysis in a generalized multilevel context. Ecology 90, 363-368. https://doi.org/10.1890/08-1034.1.

Siefert, A., Violle, C., Chalmandrier, L.L., Albert, C.H., Taudiere, A., Fajardo, A., Aarssen, L.W., Baraloto, C., Carlucci, M.B., Cianciaruso, M.V., de Dantas, L., de Bello, V., Duarte, F., Fonseca, L.D.S.S., Freschet, C.R., Gaucherand, G.T., Gross, S., Hikosaka, N., Jackson, K., Jung, B., Kamiyama, V., Katabuchi, C., Kembel, M., Kichenin, S.W., Kraft, E., Lagerstrom, N.J.B.B., Bagousse-Pinguet, A., Le, Y., Li, Y., Mason, N., Messier, J., Nakashizuka, T., Overton, J.M., Peltzer, D.A., Pérez-Ramos, I.M., Pillar, V.D., Prentice, H.C., Richardson, S., Sasaki, T., Schamp, B.S., Schob, C., Shipley, B., Sundqvist, M., Sykes, M.T., Vandewalle, M., Wardle, D.A., Lagerström, A., Bagousse-Pinguet, Y. Le, Li, Y., Mason, N., Messier, J., Nakashizuka, T., Overton, J.M., Peltzer, D.A., PérezRamos, I.M., Pillar, V.D., Prentice, H.C., Richardson, S., Sasaki, T., Schamp, B.S., Schöb, C., Shipley, B., Sundqvist, M., Sykes, M.T., Vandewalle, M., Wardle, D.A., 2015. A global meta-analysis of the relative extent of intraspecific trait variation in plant communities. Ecol. Lett. 18, 1406-1419. https://doi.org/10.1111/ele.12508. 
Stephen, J., 2005. Aridity Indexes, in: Encyclopedia of World Climatology. Springer Netherlands, pp. 89-94 https://doi.org/10.1007/1-4020-3266-8_17.

Tennekes, M., 2018. Tmap: thematic maps in R. J. Stat. Softw. 84. https://doi.org/ 10.18637/jss.v084.i06.

Urbieta, I.R., García, L.V., Zavala, M.A., Marañón, T., 2011. Mediterranean pine and oak distribution in southern Spain: is there a mismatch between regeneration and adult distribution? J. Veg. Sci. 22, 18-31. https://doi.org/10.1111/j.1654-1103.2010.01222.x.

Valladares, F, Bastias, C. C Godoy, O Granda, E. Escudero, A 2015. Species coexistence in a changing world. Front. Plant Sci. 6, 1-16. https://doi.org/10.3389/fpls.2015.00866.

Vilà-Cabrera, A., Martínez-Vilalta, J., Retana, J., 2015. Functional trait variation along environmental gradients in temperate and Mediterranean trees. Glob. Ecol. Biogeogr. 24, 1377-1389. https://doi.org/10.1111/geb.12379.

Villar, R., Ruiz-Robleto, J., Ubera, J.L., Poorter, H., 2013. Exploring variation in leaf mass per area (LMA) from leaf to cell: an anatomical analysis of 26 woody species. Am. J. Bot. 100, 1969-1980. https://doi.org/10.3732/ajb.1200562.

Villar, R., Ruiz-Benito, P., de la Riva, E.G., Poorter, H., Cornelissen, J.H.C., Quero, J.L., 2017. Growth and growth-related traits for a range of Quercus species grown as seedlings under controlled conditions and for adult plants from the field. In: Gil-Pelegrín, E., Peguero-Pina, J.J., Sancho-Knapik, D. (Eds.), Oaks Physiological Ecology. Exploring the Functional Diversity of Genus Quercus L. Springer International Publishing, Cham, pp. 393-417 https://doi.org/10.1007/978-3-319-69099-5_12.

Violle, C., Navas, M.-L., Vile, D., Kazakou, E., Fortunel, C., Hummel, I., Garnier, E., 2007. Let the concept of trait be functional! Oikos 116, 882-892. https://doi.org/10.1111/ j.2007.0030-1299.15559.x.

Walkley, A., Black, I.A., 1934. An examination of the Degtjareff method for determining soil organic matter, and a proposed modification of the chromic acid titration method. Soil Sci. 37, 29-38.
Wang, K.H., Hamzah, M.Z., 2018. Different cambial activities in response to climatic factors of three Malaysian rainforest Shorea species with different stem diameters. Trees 1-12. doi:https://doi.org/10.1007/s00468-018-1730-z.

Westoby, M., 1998. A leaf-height-seed (LHS) plant ecology strategy scheme. Plant Soil 199, 213-227. https://doi.org/10.1023/A:1004327224729.

White, P.J., George, T.S., Gregory, P.J., Bengough, A.G., Hallett, P.D., McKenzie, B.M., 2013. Matching roots to their environment. Ann. Bot. 112, 207-222. https://doi.org/ 10.1093/aob/mct123.

Wickham, H., Averick, M., Bryan, J., Chang, W., McGowan, L., François, R., Grolemund, G., Hayes, A., Henry, L., Hester, J., Kuhn, M., Pedersen, T., Miller, E., Bache, S., Müller, K., Ooms, J., Robinson, D., Seidel, D., Spinu, V., Takahashi, K., Vaughan, D., Wilke, C. Woo, K., Yutani, H., 2019. Welcome to the tidyverse. J. Open Source Softw. 4, 1686. https://doi.org/10.21105/joss.01686.

Wright, S.J., Kitajima, K., Kraft, N.J.B., Reich, P.B., Wright, I.J., Bunker, D.E., Condit, R., Dalling, J.W., Davies, S.J., DíAz, S., Engelbrecht, B.M.J., Harms, K.E., Hubbell, S.P., Marks, C.O., Ruiz-Jaen, M.C., Salvador, C.M., Zanne, A.E., 2010. Functional traits and the growth-mortality trade-off in tropical trees. Ecology 91, 3664-3674. https://doi. org/10.1890/09-2335.1.

Yuan, Z., Ali, A., Jucker, T., Ruiz-Benito, P., Wang, S., Jiang, L., Wang, X., Lin, F., Ye, J., Hao, Z., Loreau, M., 2019. Multiple abiotic and biotic pathways shape biomass demographic processes in temperate forests. Ecology 100, 1-10. https://doi.org/10.1002/ecy.2650.

Zemunik, G., Davies, S.J., Turner, B.L, 2018. Soil drivers of local-scale tree growth in a lowland tropical forest. Ecology 99, 2844-2852. https://doi.org/10.1002/ecy.2532. 